\title{
Libido and serving skills of Zebu cattle bulls
}

\section{Libido e habilidade física em touros zebuínos}

\author{
Silvio Renato Oliveira Menegassi ${ }^{1 *}$; Vanessa Peripolli2; \\ Maria Eugênia Andrighetto Canozzij; Júlio Otávio Jardim Barcellos ${ }^{4}$
}

\section{Highlights}

Young and mature Zebu bulls presented general rejection rates of $5.64 \%$ and $15.20 \%$. $0.46 \%$ and $2.29 \%$ of young and mature Zebu bulls were rejected by sexual behavior. Lack of libido and serving ability was an important problem in Zebu cattle bulls.

\begin{abstract}
The goal of this study was to evaluate the rejection rates of Zebu bulls during behavioral assessment (libido and serving ability) and the importance of this step in bull breeding soundness evaluation (BBSE). A total of 1,534 bulls reared in the state of Rio Grande do Sul, Brazil, of Nelore (1,340), Brahman (76), Guzerá (98), and Tabapuã (210) breeds were evaluated. The evaluation consisted of four steps. Step I was the general physical examination, Step II genital tract examination, Step III semen evaluation, and Step IV behavioral assessment of libido and the ability to complete copulation. To evaluate the relationship between the binary variables of approved or rejected during different steps of the BBSE, and age groups (young and mature bulls), chi-square tests and logistic regression were used. The general rejection rates in the BBSE were $5.64 \%$ and $15.20 \%$ for young and mature Zebu bulls, respectively. Problems with the sexual behavior (libido and/or serving ability) of bulls accounted for the rejection of $0.46 \%$ and $2.29 \%$ of young and mature Zebu bulls, respectively. The lack of libido and serving ability was shown to be an important problem concerning the total number of possible causes of Zebu bull rejection during the BBSE. This result suggests that the behavioral step should be performed regularly, rather than being complementary to the standard BBSE in Zebu cattle.
\end{abstract}

Key words: Andrological. Behavioral assessment. Bos taurus indicus. Failure rates.

1 Postdoctoral Degree Student at Universidade Federal do Rio Grande do Sul, UFRGS, Department of Animal Science, Porto Alegre, RS, Brazil. E-mail: programa.paat@gmail.com

2 Profa at Instituto Federal Catarinense, IFC, Araquari Campus, Araquari, SC, Brazil. E-mail: vanessa.peripolli@hotmail. com

${ }^{3}$ Researcher at Instituto Nacional de Investigación Agropecuaria, Estación Experimental INIA La Estanzuela, Programa Nacional de Investigación en Producción de Carne y Lana, Colonia, Uruguay. E-mail: mecanozzi@inia.org.uy

${ }^{4}$ Prof., Department of Animal Science, UFRGS, Porto Alegre, RS, Brazil. E-mail: julio.barcellos@ufrgs.br

* Author for correspondence

Received: Oct. 29, 2020 - Approved: May 31, 2021 


\section{Resumo}

O objetivo deste estudo foi avaliar as taxas de reprovação de touros zebuínos durante a avaliação comportamental (libido e habilidade física) e a importância desta etapa no Exame Andrológico em Touros (EAT). Foram avaliados 1.534 touros, criados no estado do Rio Grande do Sul, Brasil, das raças Nelore (1.340), Brahman (76), Guzerá (98) e Tabapuã (210). A avaliação constou de quatro etapas. Etapa I foi o exame físico geral, Etapa II o exame do trato genital, Etapa III a avaliação do sêmen, e a Etapa IV a avaliação comportamental de libido e habilidade física para completar a cópula. Para avaliar a relação entre a variável binária aprovado ou reprovado durante as diferentes etapas do exame andrológico e as faixas etárias (touros jovens e adultos), foram utilizados os testes de qui-quadrado e de regressão logística. As taxas gerais de reprovação no EAT foram de 5,64\% e 15,20\% para os touros Zebu jovens e adultos, respectivamente. Problemas no comportamento sexual (libido e/ou habilidade física) dos touros foram responsáveis pela reprovação de $0,46 \%$ e 2,29\% dos touros zebuínos jovens e adultos, respectivamente. A falta de libido e de habilidade física mostrou-se um problema importante em relação ao número total de possíveis causas de reprovação de touros zebuínos no EAT. Esse resultado sugere que a etapa comportamental deve ser realizada regularmente, ao invés de ser apenas complementar ao EAT padrão em bovinos zebuínos.

Palavras-chave: Andrológico. Avaliação comportamental. Bos taurus indicus. Taxas de falha.

In cattle, the full evaluation of reproductive health of bulls is based on the assessment of all factors that contribute to their normal function (Lopes et al., 2013). It includes a general description of the physical examination, external genital and internal genital examination, scrotal circumference measurements, evaluation of the physical and morphological aspects of the semen, and libido and serving ability evaluation (Menegassi et al., 2011b; Menegassi, Barcellos, Peripolli, Borges, \& Bernardi, 2012; Barth, 2013).

Thebehavioralassessmentparameters (libido and serving ability) influence the pregnancy rates of the herd under evaluation, because bulls must mount and impregnate a large number of females (Menegassi, Barcellos, Peripolli, \& Camargo, 2011a; Menegassi et al., 2012). The assessment is characterized by cut, erection, penile protrusion, mounting, intrusion, ejaculation, and refractory period (Menegassi et al., 2012). Additionally, the sexual behavior of bulls depends on social interaction, and can be based on genetic, environmental, nutritional, and hormonal factors, as well as sensory acuity, age, and experience (Menegassi et al., 2011a). Furthermore, the hierarchy or dominance of bulls is very important (Hancock et al., 2016).

Therefore, an andrological examination must be carefully performed, because it can lead to inconsistent results among the four stages and final performance of pasture Zebu bulls (Menegassi et al., 2011a). Because of its organizational and management complexity, veterinarians do not always assess sexual behavior during the andrological examination. Consequently, some bulls that have not undergone a full reproductive evaluation can be left in herds during the breeding season (Barth, 2013). The objective of this study was to analyze failure rates in behavioral assessment and importance of this step to be consistently included in the andrological examination of Zebu cattle. 
All procedures involving animals during this study were approved by the Animal Care Committee (CEUA) under project no. 26,250 from the Federal University of Rio Grande do Sul (UFRGS). The study consisted of recording the bull breeding soundness evaluation (BBSE) conducted on 1,534 Zebu bulls reared in the State of Rio Grande do Sul, Brazil. The data were derived from the database (2004 to 2006) of the Bull Reproductive Assessment Program (PARTO - Programa de Avaliação Reprodutiva de Touros, http://www.paat.com. br), conducted by the National Rural Education Service of Rio Grande do Sul (Serviço Nacional de Aprendizagem Rural do Rio Grande do Sul, SENAR-RS). Bulls from the following breeds were evaluated: Nelore (1,340), Guzerá (98), Tabapuã (210), and Brahman (76). The animals evaluated were grouped into two age classes: young (2 or 3 years old; 419 ) and adult bulls (4-10 years old; 1,115). These age classes were formed considering that young bulls are the ones sold at auctions and mature bulls are animals with activity in the field.

The BBSE was performed according to the guidelines of the Western Canadian Association of Bovine Practitioners (Barth, 2013), developed for both Bos taurus taurus and Bos taurus indicus breeds. This methodologywas chosen because it considers the behavioral examination to be mandatory. The evaluation included four steps:

Step I: General physical examination, including the eyes, teeth, body condition score, feet, legs, and locomotor apparatus.

Step II: Genital tract examination, including the sheath, penis, scrotum, testicles, epididymis, scrotal circumference, and examination of the internal genital tract (vesicular glands and ampulla of the vasa deferens) by rectal palpation. Scrotal circumference (SC) was measured by pulling the testicles to the bottom of the scrotum and placing a metal measuring tape around the widest circumference. This procedure was repeated immediately to check the measurements. The rejection criteria were SC $<28 \mathrm{~cm}$ in young bulls and $<30 \mathrm{~cm}$ in mature bulls of the Zebu breeds. Bos taurus indicus bulls often have more elongated testicles than Bos taurus taurus, which causes a smaller scrotal circumference (Coulter, Mapletoft, Kozub, \& Cates, 1987; Menegassi et al., 2011b).

Step III: Semen evaluation was subjectively performed and mass motion (MM) was determined by placing a $10 \mu \mathrm{L}$ drop of semen on a pre-warmed microscope slide, and the edge of the drop was examined using an optical microscope at 20x magnification. The MM received a subjective score ranging from 0 to $5: 0=$ no swirl, $1=$ no swirl with generalized oscillation of individual sperm only, 2 = very slow distinct swirl, 3 = slow distinct swirl, $4=$ moderately fast distinct swirl and eddies, and 5 = fast distinct swirls and eddies with the appearance of good-quality semen. Sperm motility (M) was examined under a brightfield microscope at a magnification of $40 x$ with a $5 \mu \mathrm{L}$ aliquot of diluted semen in $2.94 \%$ sodium citrate solution placed on a warmed $\left(37^{\circ} \mathrm{C}\right)$ slide and covered with a coverslip. Sperm M was subjectively evaluated as the percentage of sperm movement (0 to 100\%). Vigor (VIG) was evaluated using a scale from 0 to 5 based on the progressive movement of the sperm, where $0=$ none, 1 = very weak, 2 = weak, 3 = intermediate, 4 = strong, and $5=$ very strong. Additionally, each semen aliquot was diluted in buffered saline-formaldehyde (1:10), and sperm morphology was analyzed using a phase-contrast microscope. Semen 
was collected by electroejaculation (Autojac ${ }^{\circledR}$, Neovet, Campinas, SP, Brazil) or transrectal massage of the seminal vesicles and ampullae of the vasa deferentia.

Step IV: Behavioral examination, including the libido stage and serving ability. Libido was considered as the intention, drive, or desire of the bull to mate, and serving ability as the completion of mounting. The steps were conducted in a pen with one or two cows restrained in an artificial insemination chute; the use of cows in estrus was not regarded as necessary. Initially, bulls were placed together in an adjacent pen, such that they could observe other bulls mounting for 10 to $15 \mathrm{~min}$ to be pre-stimulated. Bulls were tested in pairs for a maximum time of 10 to $20 \mathrm{~min}$. The result was interpreted as the presence or absence of libido and/or serving ability. It was characterized by courtship, erection, penile protrusion, mounting, intromission, ejaculation, and a refractory period. If a bull seemed too restless, lethargic, or aggressive, it was given another opportunity to express its sexual behavior; however, this time it was with a cow in estrus in a pen or at pasture.
The BBSE sequence was a general clinical examination, special clinical examination, seminal examination, and behavioral examination (libido and serving capacity). When the bull failed in one of the steps, the subsequent stage was not performed. Thus, the results of the special clinical examination corresponded only to those bulls that were approved in the general clinical examination. Likewise, the seminal examination included only bulls approved in the general and special clinical examinations. The general failure rate for these three steps was cumulative, although the number of bulls that would have failed in more than one step could not be quantified. Some farms did not have an appropriate structure, and not all bulls approved in the first three steps were submitted to the assessment of libido and serving ability. The number of bulls included in Step IV (656) was lower than that approved in Steps I (1,534), II $(1,441)$, and III $(1,309)$ (Table 1), but this did not affect the statistical analyses.

Table 1

Rejection percentage of young and adult Zebu bulls according to Bull Breeding Soundness Evaluation

\begin{tabular}{|c|c|c|c|c|c|c|c|}
\hline \multirow[b]{2}{*}{ Step } & \multicolumn{3}{|c|}{ Young } & \multicolumn{3}{|c|}{ Adult } & \multirow[b]{2}{*}{$\begin{array}{l}\text { Mean rejection } \\
\text { percentage (\%) } \\
\text { for both groups }\end{array}$} \\
\hline & $\mathrm{N}$ & $\begin{array}{c}\text { Bulls } \\
\text { rejected (n) }\end{array}$ & $\begin{array}{c}\text { Rejection } \\
\text { percentage } \\
(\%)\end{array}$ & $\mathrm{n}$ & $\begin{array}{l}\text { Bulls } \\
\text { rejected (n) }\end{array}$ & $\begin{array}{l}\text { Rejection } \\
\text { percentage } \\
(\%)\end{array}$ & \\
\hline General physical & 419 & 7 & $0.46^{\mathrm{bB}}$ & 1115 & 73 & $4.76^{\mathrm{aB}}$ & $5.22^{\mathrm{B}}$ \\
\hline Genital & 412 & 62 & $4.26^{\mathrm{bA}}$ & 1042 & 83 & $5.71^{\mathrm{aA}}$ & $9.97^{A}$ \\
\hline Semen & 350 & 6 & $0.46^{\mathrm{B}}$ & 959 & 32 & $2.44^{\mathrm{C}}$ & $2.90^{C}$ \\
\hline Behavioral & 160 & 3 & $0.46^{\mathrm{B}}$ & 496 & 15 & $2.29^{\mathrm{D}}$ & $2.74^{\mathrm{D}}$ \\
\hline Mean & 335 & 20 & 1.41 & 903 & 51 & 3.80 & 5.20 \\
\hline Total & 419 & 78 & $5.64^{b}$ & 1115 & 203 & $15.20^{\mathrm{a}}$ & 20.83 \\
\hline
\end{tabular}

$\mathrm{N}$ : number of animals. Different lowercase letters in rows (within steps) and different capital letters in columns (between steps) indicate statistical differences $(P<0.05)$. 
Statistical analyses were performed using the SAS v. 9.4 program (Statistical Analysis System Institute, Cary, North Carolina, USA). To analyze the relationship between the approved or rejected binary variables in the different BBSE steps and the age groups (young and adult bulls), the chi-square test (PROC-FREQ), and the logistic regression (PROC LOGISTIC) were used. The level of significance for the statistical tests was $5 \%$.

The total rejection rates in the andrological examination were $5.64 \%$ and $15.20 \%$ for young and adult bulls, respectively $(P<0.0001)$. The BBSE steps (general physical examination, genital tract examination, semen evaluation, and behavioral evaluation) exhibited significant differences in terms of mean rejection percentage for both groups $(\mathrm{P}<0.0001)$. The odds ratio test for the general physical examination showed that the adult bulls were four times more likely to be rejected than young bulls (odds ratio $=4.123 ; 95 \%$ confidence interval limits $=1.883-9.030$ ), although for the genital tract examination, young bulls were twice as likely to be rejected than adult bulls (odds ratio = 2.044 (1/0.489); $95 \%$ confidence interval limits $=0.344-0.694$ ). For the semen examination, adult and young bulls were equally likely to be rejected (odds ratio $=1.979 ; 95 \%$ confidence interval limits = 0.880-5.290). In the present study, problems in the sexual behavior of bulls were not influenced by age groups $(P=0.4391)$, with rejection percentages of $0.46 \%$ for young bulls and $2.29 \%$ for adult bulls (Table 1 ).

The lack of libido and/or serving skills exhibited the importance of these problems in relation to the total number of bull rejection causes (Tables 1 and 2). In young bulls, behavioral assessment was as significant as semen assessment. In adult bulls, it was responsible for the rejection of more bulls than the size of scrotal circumference, and pathologies associated with testicles and seminal vesicles.

\section{Table 2}

\section{Main rejection causes of the young and adult Zebu bulls evaluated}

\begin{tabular}{|ccccccc|}
\hline & \multicolumn{4}{c}{ Young } & \multicolumn{3}{c|}{ Adult } \\
\cline { 2 - 7 } Rejection Causes & $\mathrm{n}$ & $\begin{array}{c}\text { Bulls } \\
\text { rejected }(\mathrm{n})\end{array}$ & $\begin{array}{c}\text { Rejection } \\
\text { percentage }(\%)\end{array}$ & $\mathrm{n}$ & $\begin{array}{c}\text { Bulls } \\
\text { rejected (n) }\end{array}$ & $\begin{array}{c}\text { Rejection } \\
\text { percentage (\%) }\end{array}$ \\
\hline Body condition score & 419 & 6 & $0.39^{\mathrm{bE}}$ & 1115 & 52 & $3.39^{\mathrm{aA}}$ \\
\hline Scrotal circumference & 402 & 17 & $1.18^{\mathrm{aA}}$ & 1037 & 14 & $0.97^{\mathrm{bF}}$ \\
\hline Testicles & 402 & 14 & $0.97^{\mathrm{B}}$ & 1037 & 26 & $1.81^{\mathrm{D}}$ \\
Seminal vesicles & 402 & 12 & $0.83^{\mathrm{C}}$ & 1037 & 15 & $1.04^{\mathrm{E}}$ \\
\hline Semen & 350 & 6 & $0.46^{\mathrm{D}}$ & 959 & 32 & $2.44^{\mathrm{B}}$ \\
\hline Libido and/or Serving ability & 160 & 3 & $0.46^{\mathrm{D}}$ & 496 & 15 & $2.29^{\mathrm{C}}$ \\
\hline
\end{tabular}

$\mathrm{N}$ : number of animals. Different lowercase letters in rows (within rejection causes) and different capital letters in columns (between rejection causes) indicate statistical differences $(P<0.05)$. 
Observing the absence or presence of libido and/or serving skills during the behavioral stage is more fundamental in Bos taurus indicus. In this subgroup, unlike the Bos taurus taurus subgroup, the exam is more unstable, because they are more reactive to human presence (Menegassi et al., 2011a).

Behavioral assessment of bulls is not always performed, although according to Menegassi et al. (2011a), in a population of Bos taurus taurus bulls, percentages from $3.55 \%$ to $5.24 \%$ in young bulls and $3.54 \%$ to $6.37 \%$ in mature bulls failed because of the low quality and quantity of semen, physical defects that prevent the animal from copulating, and lack of libido. In this study, the total accumulated rejection rates were in line with the rates expected in this stage for young and adult bulls, unlike previous work with the Bos taurus taurus subspecies. Zebu breeds face a higher failure rate in mature bulls than in young ones, as well as in other breeds (Menegassi et al., 2011a).

Additionally, several factors can affect the expression of libido in the field (Petherick, 2005), and the conditions under which this step is performed can influence the results. Although the step evaluating the libido and serving ability may not be sufficient to accurately determine pregnancy rates (Parkinson, 2004), it can be stated that the chances of obtaining good pregnancy rates are greater when bulls pass not only in the general physical exam, genital tract exam, and semen evaluation, but also the behavioral stage of the evaluation. The rejection rates in the bulls during the behavioral assessment demonstrated that this step should be mandatory, instead of being a complementary test during the andrological examination.
Rural properties are generally not prepared to conduct behavioral assessments because of the lack of environmental and organizational structures. Because this examination step requires more care and takes time, especially when Zebu bulls are examined, veterinarians rarely perform it.

Currently, with the patent for the System and Method for Monitoring Behavior and Reproductive Activity of Animals in Herd (BR102018005455-4), using an electronic methodology, unlike other devices available to date, it will be possible to confirm the presence of libido with penile penetration in Bos taurus indicus bulls. This will facilitate the premise that we can, from the effectuation of this patent, use this finding of paramount importance in the behavioral evaluation of Zebu cattle (Muller \& Menegassi, 2018).

Behavioral assessment, as one stage of andrological examination, proved to be important for the correct assessment of Zebu bulls.

\section{Acknowledgments}

The authors thank the Brazilian Council of Scientific and Technological Development (CNPq) and the Coordination for the Improvement of Higher Education Personnel (CAPES - Project CAPES/PNPD n. 2842/2010) for financing and scholarship.

\section{References}

Barth, A. D. (2013). Bull breeding soundness evaluation manual. Saskatoon: The Western Canadian Association of Bovine Practitioners. 
Coulter, G. H., Mapletoft, R. J., Kozub, G. C., \& Cates, W. F. (1987). Scrotal circumference of two-year-old bulls of several beef breeds. Theriogenology, 27(3), 485-491. doi: 10.1016/0093-691X(87)90236-6

Hancock, A. S., Younis, P. J., Beggs, D. S., Mansell, P. D., Stevenson, M. A., \& Pyman, M. F. (2016). An assessment of dairy herd bulls in southern Australia: 1. Management practices and bull breeding soundness evaluations. Journal of Dairy Science, 99(12), 9983-9997. doi: 10.3168/ jds.2015-10493

Lopes, F. G., Koetz, C., Jr., Barca, F. A., Jr., Claus, L. A. M., Menegassi, S. R. O., \& Carrer, L., $F^{\circ}$. (2013). Utilização de dois métodos de classificação andrológica por pontos em touros jovens da raça Braford. PUBVET, 7(12), 1002-1136.

Menegassi, S. R. O., Barcellos, J. O. J., Peripolli, V., Borges, J. B. S., \& Bernardi, M. L. (2012). Causes of rejection of beef bulls in breeding soundness evaluation. Revista Brasileira de Zootecnia, 41(7), 16481653. doi: 10.1590/S1516-3598201200 0700013

Menegassi, S. R. O., Barcellos, J. O. J., Peripolli, V., \& Camargo, C. M. (2011a). Behavioral assessment during breeding soundness evaluation of beef bulls in Rio Grande do Sul. Animal Reproduction, 8(3-4), 77-80.
Menegassi, S. R. O., Barcellos, J. O. J., Peripolli, V., Pereira, P. R. R. X., Borges, J. B. S., \& Lampert, V. N. (2011b). Measurement of scrotal circumference in beef bulls in Rio Grande do Sul. Arquivo Brasileiro de Medicina Veterinária e Zootecnia, 63(1), 87-93. doi: 10.1590/S0102-0935 2011000100014

Muller, I., \& Menegassi, S. R. O. (2018). Pedido nacional de invenção, modelo de utilidade, certificado de adição de invenção e entrada na fase nacional do PCT. Sistema e método de monitoramento de comportamento e atividade reprodutiva de animais em rebanho. 20/03/2018 BR102018005455-4 Brasil: Universidade Federal do Rio Grande do Sul. Porto Alegre.

Parkinson, T. J. (2004). Evaluation of fertility and infertility in natural service bulls. Veterinary Journal, 168(3), 215-229. doi: 10.1016/j.tvjl.2003.10.017

Petherick, J. C. (2005). A review of some factors affecting the expression of libido in beef cattle and individual bull and herd fertility. Applied Animal Behaviour Science, 90(3-4), 185-205. doi: 10.1016/j. applanim.2004.08.021 
